\section{Imposing total import bans}

\section{Washington}

RESPONDING to calls from conservation groups, President George Bush last week announced a total ban on the import of elephant ivory to the United States. The move came after a study by the international Ivory Trade Review Group showed that the population of elephants in Africa has dropped from 1.3 million in 1979 to roughly 750,000 two years ago, mostly from illegal poaching. Limited trade in ivory has so far been permitted by the Convention on the International Trade in Endangered Species (CITES).

Attention to the plight of the elephant was stepped up last year, after the USbased African Wildlife Foundation called for a consumer embargo of ivory products to stem the demand for ivory, and deflate its price (see Nature 333, 290; 1988). At the time, such an approach was deemed to be the best way to discourage poaching without a total ban on the sale of ivory.

In October, the 102 parties of CITES

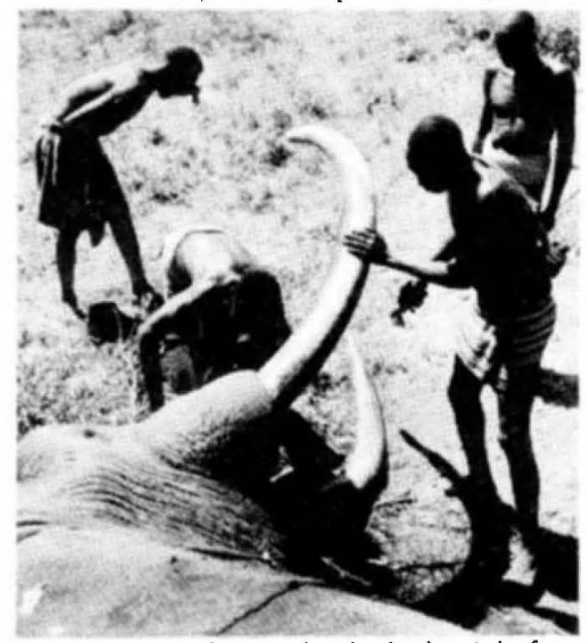

Poachers examine a dead elephant before cutting out the valuable ivory tusks.

will meet in Switzerland to vote on an international across-the-board ban on ivory trade. In the meantime, World Wildlife Fund president Russell Train predicts an "elephant holocaust" across Africa if the rest of the world continues to accept ivory imports.

Carol Ezzell

\section{Parls}

THE French environment minister, Brice Lalonde, last week announced that France is to operate a total ban on imports of raw or carved ivory. The decision, and that announced by US President George Bush (see above), follow a call two weeks ago by the British environment minister, Lord Caithness, for a multilateral ban on new ivory trade.

Support has also come from the European Commission, which agreed at a meeting last Thursday to ban all imports of raw and worked ivory. The ban will take effect within the next month, but Britain and France will operate an immed- iate unilateral ban.

Most affected will be African countries, who have so far been able to continue to trade under Annex 2 of CITES, which allows quotas of exports. Indian elephants already come under Annex 1, which requires a total ban.

By allowing African nations to manage their own quotas under Annex 2, CITES has attracted criticism for, unwittingly, 'laundering' illegal ivory trade. In ten years, the population of African elephants has decreased despite the controls. While the legal export quotas from African countries total about 118 tonnes of ivory each year, Hong Kong, Japan and China last year together declared imports over three times greater than this.

The import bans will be an encouragement to African countries seeking a total ban on international ivory trading. But, unless the import ban is supported by Far East countries, where much ivory is carved, it will do little to curb illegal trading.

Peter Coles

MEDICAL RESEARCH

\section{Health service reform worries MRC}

\section{London}

MedicAl research and research training in Britain could suffer as a result of the government's planned reform of the National Health Service (NHS), warns the Medical Research Council (MRC) in a written response to the plans.

Tighter control over budgets by general practitioners and self-governing hospitals could lead to the neglect of medical research, which in the short term adds to the costs of medical care, it says. Although the government states in the white paper that it is committed to maintaining the quality of medical education and research, the MRC complains that there is little information about how this commitment will be honoured. It must ensure, says the MRC, that there is no financial advantage in opting out of medical research, and should introduce positive discrimination to encourage NHS staff to become involved with research. The MRC also calls for the appointment of a director at top level rank to take responsibility for identifying research needs and ensuring that advances are translated into practice.

Other MRC concerns are that it will be more difficult to recruit high quality personnel in academic medicine and clinical research if hospitals can determine pay and conditions for staff, and that fragmentation of the NHS will make it more difficult to carry out multicentre clinical trials, research studies and evaluations of new technologies.

Christine McGourty

\section{Academies' global view}

\section{Moscow}

ThE United States and the Soviet Union are to cooperate to tackle environmental problems. Earlier this month, president of the USSR Academy of Sciences Guriy Marchuk and head of the delegation of the US National Academy of Sciences, president of the National Engineering Academy Robert White, signed a memorandum to establish a United Inter-Academy Committee for Global Ecology. The Committee will comprise the two countries' leading experts; hundreds of research institutes will take part in joint studies.

There was no representative for the nuclear sciences or the nuclear industry at the meeting, perhaps surprising in light of the importance of nuclear power. The opinion of US ecologists was voiced by Robert White, once head of the US hydrometeorological service. He said that to prevent the greenhouse effect, it was necessary to examine ways of energy production which did not involve discharges of carbon dioxide into the atmosphere. Although public opinion in many countries is hostile to nuclear power (see page 499), safe nuclear power stations can be built today and this technology must be considered alongside other alternative sources of energy.

The first decisions on the co-ordinated directions of studies will be discussed at the next Committee session in Washington next week. Yuri Kanin/Novosti

\section{COMPUTER ESPIONAGE}

\section{Hacker dies}

\section{Munich}

THE body of a 24-year-old West German computer hacker was found, badly burned, in the woods near Braunschweig on 1 June. The hacker, Karl Koch, was one of two West Germans who told authorities of a plot to pass classified information from Western computer systems to Soviet intelligence agents (see Nature 338, 108; 1989).

Authorities found "no evidence" of foul play in Koch's death, according to spokesman Hans Helmut Kehr of the Hildesheim Public Prosecutor's Office. Near Koch's charred remains were found a petrol can and a lighter. Kehr called the case a suicide.

In the week's prior to his death Koch was reportedly in a disturbed condition. But Clifford Stoll of the Harvard Smithsonian Center for Astrophysics and others close to the espionage case consider the suicide hypothesis "doubtful".

Indictments by the West German Federal Prosecutor are expected in the hacker espionage case at the end of the summer.

Steven Dickman 